\title{
Performance of Rastriya Banijya Bank Limited in Nepal
}

\section{Rishikesh Panthi Ph. D Scholar ${ }^{1 *}$, Sanjita Dahal ${ }^{2}$, Shree Krishna Thapa M.Phil. Scholar ${ }^{3}$}

\author{
${ }^{1}$ Faculty of Management Tribhuvan University Nepal \\ ${ }^{2}$ Faculty of Management Purbanchal University Nepal \\ ${ }^{3}$ Department of Public Administration Tribhuvan University, Nepal
}

DOI: $10.36348 /$ sjef.2021.v05i02.002 $\quad$ | Received: 23.01.2021 | Accepted: 06.02.2021 | Published: 13.02.2021

*Corresponding author: Rishikesh Panthi Ph. D Scholar

\section{Abstract}

For the survival and growth, every organization should be capable to translate its mission, vision, goals, objectives, plans and programs enhancing performance. Rastriya Banijya Bank limited (RBBL) was incorporated in 1966 through enactment of special statute on Rastriya Banijya Bank (RBBL) Act.1966, with mains objective to provide banking and financial service related business in the country. In this context, this article explores the capacity and performance level of Rastriya Banijya Bank limited and discussion about contribution of RBBL in banking business in Nepal. Continuous performance is the objective of any organization because only through performance, organizations are able to grow and progress. For the discussion, about Performance of RBBL, operating status of RBBL, financial status of RBBL, total investment Share and loan investment, dividend received, contribution on business credit transfer, Revenue generation, Shareholder's Fund/networth, working capital, administrative and unfunded liabilities of RBBL on the based on PBM theory assumptions. Secondary data are obtain from Ministry of Finances and National planning commission and some of the key personnel of the RBBL are also interviewed. The finding shows that there are still very important roles of RBBL for service delivery system, social and economic development, and the roles of income Tax; value added tax and not taxable-tax collection and social welfare, Employees' generation, curtailing, syndicate and market control, the role of crisis management and emergency situation etc.

Keywords: Rastriya Banijya Bank, Performance, Efficiency, Effectiveness, Quality, Service Delivery, Contribution, Banking Business, Supply Management.

Copyright (C) 2021 The Author(s): This is an open-access article distributed under the terms of the Creative Commons Attribution 4.0 International License (CC BY-NC 4.0) which permits unrestricted use, distribution, and reproduction in any medium for non-commercial use provided the original author and source are credited.

\section{INTRODUCTION}

Particularly after the great depression of 1930s, Public enterprises were created in both developed and developing countries in the World for economic and social development [1]. Nepal was also not exception for establishing such entities. Nepal establishes more than five dozen of such enterprises up to the late Sixties. Rastriya Banijya Bank (RBB) was one of these corporations related to Banking sector, which has been established in Nepal with the main objective of providing banking business in Nepal as well as institutional credit for enhancing the production and productivity of the business sector in the country, Rastriya Banijya Bank (RBB), Nepal was established in 1966 through enactment of special statute on Rastriya Banijya Bank (RBBL) Act.1966, as successor to the commercial Bank.

Rastriya Banijya Bank Limited (RBBL) is an "A" class autonomous organization largely owned by
Government of Nepal. The bank has been working as a premier business credit institution since last three decades, contributing the more than $50 \%$ of institutional business credit supply in the country. Hence, business finance is the principal operational area of RBBL. Furthermore, the bank has also involved in commercial \& rural credit banking operations.

The enactment of Bank and Financial Institution Act (BAFIA) abolished all Acts related to financial institutions including the RBBL Act, 1966. In line with the BAFIA, RBBL has been incorporated as a public limited company on july14, 2005. Thus, RBBL operates as a "A" category financial institution under the legal framework of BAFIA and the Company Act, 2053.

At present, RBBL has been providing business credit from 238 branches, less banking (RLB) from 99 branches and 204 ATMs all over the country by core 
Rishikesh Panthi et al., Saudi J Econ Fin, Feb, 2021; 5(2): 43-50

banking system (MOF:2020). Furthermore, It is also providing Locker facilities, ATM facilities, Demat service, C-ASBA, RBB mobile banking, RBB Pos service, RBB remit, RBB house loan, Vehicle loan, Fixed Account, Visa Debit Card, Internet Banking services, RBBL providing the connect IPS, and Electronic Banking etc.

In this back ground, it is curious that why some of the Nepalese Public Banks are able to perform well and the others are not able to make profits. To what extent the bank contributing to business credit supply? What are the major challenges of banking management in Nepal? Against, this backdrop, this research article has been attempted to analyze and review the financial efficiency and operational condition of RBBL. The researcher discussion 5 years trends analysis of Nepalese public bank (RBBL) from different corner i.e. financial efficiency of Government owned Public Bank, government share investment, loan \& dividend received from RBBL, RBBL contributions on business credit supply, revenue \& shareholders' fund and also analysis of working capital, administrative expenditure \& unfunded liabilities of RBBL. For the purpose of writing this article the financial and operation performance of RBBL has been reviewed. In addition, some of the key informants were interviewed. The secondary information was triangulated with primary information for substantiating the factual information.

\section{OBJECTIVES AND METHODOLOGY}

The primary objective of this study is to review and analyze the overall performance trends of RBBL in Nepal. In order to achieve the objective, the relevant information and data have been collected from both primary and secondary sources. Primary data was collected through personnel interview with policy makers, academician, CEO, executive committee, key personnel of RBBL and others. The secondary sources was included the various publication of ministry of finance (MOF), National planning commission (NPC) ,Central Bureau of Statistics(CBS), Research and survey reports of various national and internationals institutions, Books, Journals, thesis and dissertation Reports etc.

\section{THE LITERATURE REVIEW AND ANAL YTICAL FRAMEWORK}

In this section, literature related to Performance Based Management (PBM) and Public Bank performance reviewed to provide a background of the study, to identify the relevant variables and to formulate an analytical framework for the study. The concept of organizational performance or effectiveness holds a central position in the management of both public and private organizations as well as in the field of organizational research over the last decades, concerns for efficiency, productivity, excellence and total quality have become increasingly widespread in western organizations [2-4]. Performance Management (PM) is more than the end of the year appraisal about it translating goals in to results. Performance Management focuses not only on individual employees but also on teams, programs, processes and the organization as a whole. Performance is a multidimensional concept. On the most basic level [5].

Severals studies that have examined in the past issues of the performance evaluation of public enterprises include [6-15]. The majority of previous study examine the development of a general framework for performance evaluation of public enterprises, although the determination of the appropriate performance evaluation criteria for evaluation of public enterprises. Performances are directly related to the objectives of each public enterprise [13, 15, 16]. The others significant determining issue of public enterprises objectives is a social as well as a commercial role so that there is multiple objectives in the operation of PEs including efficiency, profitability, income distribution and contribution to the implementation of macroeconomic policies [13]. Organizational Performance may be defined as the transformation of inputs in to outputs for achieving certain outcomes with regard to its content, performance informs about the relationship between minimum effective cost (economy) and outputs (efficiency) or achieved outcome (effectiveness) [17, 4].

Organizational performance refers to ability of an enterprise to achieve such objective as high profit, quality product, large market share, good financial results and survival at pre-determined time using relevant strategy for action [18]. The current debate on terms like performance, productivity and quality is still confusing, since and adequate and commonly accepted definitions are rarely found within both academic and commercial circles [19, 20]. However, performance is the Umbrella term of excellence and includes profitability and productivity as well as other non-cost factors such as quality, speed, delivery and includes profitability and productivity as well as other non-cost factors such as quality, speed, delivery and flexibility $[19,21]$.

For instance, Venkatraman \& Ramanujan [22] consider three aspects of performance among them are financial performance, business performance and organizational effectiveness and the later have been subsequently known as organizational performance [23].

Continuous performance is the focus of any organization because only through performance, organizations are able to grow and progress [24]. The main objectives of organizational Performance evaluation is refers to ability of an enterprise to achieve such objectives as high profit, quality product, large 
Rishikesh Panthi et al., Saudi J Econ Fin, Feb, 2021; 5(2): 43-50

market share, good financial results and survival at predetermined time using relevant strategy for action [18, 25]. Performance management is important for an organization, as it helps organizations ensuring employees are working hard to contribute to achieving the organization's mission and objective. Organizational performance can also be used to view how an enterprise is doing in terms of level of profit, market share and product quality in relation to other enterprises in the same industry. Consequently, it is a reflection of productivity of members of an enterprise measured in the terms of revenue, profit, growth, development and expansion of the organization [25]. Performance measurement is made up of a set of procedures that help government organizations optimize their business performance and it provides a background for organizing, automating and analyzing business (tendency) trend, metric, process and systems that drive business performance.

Furthermore, Sharma [27] conducted on his research Performance of Public Sector Bank by using CAMEL model analysis. He also comparison the performance of public Bank to others bank as well. The research finding shows that public sector bank gives better performance than others private Banks. The result of Public Bank was satisfactory then private Banks [27, $26,14]$.

Similarly, Prasad \& Ravinder [28] were conducted research about the performance of Indian Banks, which was related to the Public sectors. The sample size of banks was $20 \&$ they applied CAMEL model to find out financial performance. Researchers find outs the comparative study of some Indian banks. An Andhra bank was one of the highest best-performed Banks in the India. Which were also followed by the $\mathrm{P}$ \& S Bank \& Bank of Baroda, at last Central Bank of India showed very low performance [28].

Furthermore, Hui [29] tried to find out the factors affecting the performance of Nepalese Commercial Banks By using various camel ratios such as return on asset (ROA), return on equity (ROE), capital adequacy ratio (CAR) etc. As Public sector banks have higher total assets compared to joint venture or domestic private banks, thus ROA was found higher whereas overall performance of public sector was unsound because ROE and CAR of joint venture and private banks was found superior. The financial performance of public sector banks is being eroded by other factors such as poor management, high overhead cost, political intervention, low quality of collateral etc. $[29,30,4]$.

Similarly, Malhotra [31] measured the financial performance of Indian public sector banks asset by camel model and applying the tests like Anova, f-test and arithmetic test for the data collected for the year 2007-2011. They concluded that the top two performing banks were bank of Baroda and Andhra bank due to high capital adequacy and asset quality and the worst performer was united bank of India because of management inefficiency, low capital adequacy and poor assets and earning quality. Central Bank of India is at last position followed by UCO bank and bank of Maharastra [31, 30].

Chaudhary [32] conducted a study to measure the right performance of public and private sector banks by the use of secondary data collected from annual reports, periodic plans, website etc. for the year 2009 2011. He also found out that in every aspect, private sector bank has performed better than public sector banks and itwas growing at faster than public Banks $[32,30,4]$.

\section{Theoretical Considerations}

The study draws upon the theoretical insights of the academic literature on Performance Based Management (PBM) theory. Performance-based management (PBM) theory is a systematic approach to performance improvement through an ongoing process of establishing strategic performance objectives, measuring performance, collecting, analyzing, reviewing and reporting performance data and using that to drive improvement. Performance measurement is the comparison of actual levels of performance to preestablished target level of performance. It is generally indicates inputs, activities, outputs, outcomes and goals. The main objective of this approach is to increase efficiency and effectiveness in terms of organizational performance and service delivery.

\section{Indicators of Performance Evaluation/Measurement}

Organizational performance evaluation technique and methods used to measure and manage it have been a current debate in both management theory and practice. Performance evaluation process of organization generally involves in both implementation and monitoring strategy of the organization that sets of standard ratio between the goals purposed and the results obtained [33, 23]. Performance measurement as the sets of metrics used to quantify both the efficiency and effectiveness of actions [34]. Hancott, point out that, a number of indicators have been adopted to measure organizational performance since mid-1900, such as profit growth rate, net or total assets growth rate, return on sales, shareholder's return, growth in market share, number of new products, return on net assets etc. [35]. A number of studies have applied in different ways to evaluate organizational performance [36-39] review 17 organizational effectiveness models, integrate this measurement of organizational performance from various studies and generalize this measurement in to three dimensions: financial performance, business performance and organizational effectiveness. In addition, Delaney and Huselid [40] suggest two ways to assess organizational performance 
Rishikesh Panthi et al., Saudi J Econ Fin, Feb, 2021; 5(2): 43-50

there are organizational performance and marketing performance.

Later, Tippins and Sohi [41] purpose organizational performance is measured on four dimensions. These are relative profitability, return on investment, customer retention, and total sales growth. The Economic Advisory council in its report titled "PEs in India: Some current issues" Suggests different parameters of performance evaluation Indicators such as financial, production, investment efficiency, productivity and social audit. Furthermore, Victor Powell [42] has explained that there are several indicators for measuring PEs performance such as General performance, management performance, Investment performance, costs break down (input coefficient and physical performance (i.e. resource use). Previous research had used many indicators to measure organizational performance such as profitability, gross profit, return on asset (RoA), return on investment (RoI), return on equity (RoE), return on sale $(\mathrm{RoS})$, revenue growth, market share, sales growth and operational efficiency [43, 44, 4].

There are various indicator of organizational performance evaluation of public Bank but in this study focused to analyze and review the financial efficiency and operational condition of RBBL. The researcher discussion 5 years trends analysis of Nepalese Public Bank RBBL from different corner i. e., operating status of Nepalese Bank in different fiscal year, financial efficiency of Government owned Public Bank RBBL, government share investment, loan $\&$ dividend received from RBBL, RBBL contributions on business credit supply, contribution on revenue generations \& shareholders' fund and also analysis of working capital, administrative expenditure \& unfunded liabilities of RBBL.

\section{ANALYSIS AND DISCUSSION}

\section{The financial status of Agriculture Development Bank Limited.}

The corporate from RBBL in Nepal existed only in 1966 when the government of Nepal decided to go for providing institutional credit for enhancing the business in the business sector in the country. RBBL is in the first commercial bank in Nepal. Financial performance measures of public Bank depend upon the economic viability, including directing cost comparison, ignore both of the non-cash element and the time of value of money (Panthi, 2019c) [4]. Bank investment out of general revenue to support overall economic development rather than produce profit so that RBBL performance focused on Net capital investment, overall net profit/loss, total operating income, total operating profit/ loss, operating profit to net capital investment percentage and cumulative profit/loss were taken important financial indicator of RBBL performance evaluation which was given in table-1

Table-1: Financial Efficiency (profit/loss) of RBBL

\begin{tabular}{|l|l|l|l|l|l|c|c|}
\hline S.N. & $\begin{array}{l}\text { Fiscal } \\
\text { Year } \\
\text { (FY) }\end{array}$ & $\begin{array}{l}\text { Net Capital } \\
\text { Investment } \\
\text { (in } \\
\text { millions) }\end{array}$ & $\begin{array}{l}\text { Total } \\
\text { operating } \\
\text { income (in } \\
\text { millions) }\end{array}$ & $\begin{array}{l}\text { Total } \\
\text { operating } \\
\text { Cost (in } \\
\text { millions) }\end{array}$ & $\begin{array}{l}\text { Total Net } \\
\text { operating } \\
\text { profit/Loss(in } \\
\text { millions) }\end{array}$ & $\begin{array}{l}\text { Cumulative } \\
\text { Profit/ Loss } \\
\text { (millions) }\end{array}$ & $\begin{array}{l}\text { Operating Profit } \\
\text { to Net Capital } \\
\text { Investment }(\%)\end{array}$ \\
\hline 1. & $2013 / 14$ & NA & 59481.99 & 65004 & 13101 & -19855 & 15.25 \\
\hline 2. & $2014 / 15$ & NA & 60417.10 & 69199 & 18367 & -43658 & 21.38 \\
\hline 3. & $2015 / 16$ & NA & 53745.26 & 75043 & 46439 & 62549.47 & 66.57 \\
\hline 4. & $2016 / 17$ & 95500.49 & 67193.76 & 684538 & 23553 & -99831.25 & 24.66 \\
\hline 5. & $2017 / 18$ & 1064314 & 72640 & 100929 & 27763 & -115253.27 & 21.63 \\
\hline
\end{tabular}

Source: Original Data from MOF: 2013/14/15/16/17/18

In above, table shows that net operating income has been increasing and reached was Rs.60417.10 millions in FY 2014/15 which was only Rs. 59481.99 millions in previous FY2013/14. The total operating profit has reached 18367 millions in FY 2014/15 which was Rs.13101 millions in last FY2013/14.The cumulative loss has been increasing and reached Rs. -43658 and operating profit to net capital investment increasing by $21.38 \%$ which was subsequently Rs.-19855 millions and $15.25 \%$ in last FY2014/15.

Furthermore, net capital investment has been reached Rs.95500.49 million in FY 2016/17. The total operating income has been increasing and reached Rs.67193.76 millions in FY 2016/17 which was only Rs.53745.26 millions in previous FY2015/16. The total operating cost had reached Rs.684538 million in FY2016/17 which was Rs.75043 millions in last FY2015/16. The net operating profit has been decreasing and reached Rs.23553 millions in FY2016/17 which was Rs.46439 million in FY2015/16. The cumulative loss has significantly increasing and reached Rs.-99831.25 millions in FY2016/17 which was found positive Rs.62549.47millions in last FY $2015 / 16$. The operating profit to net capital investment percentage has been decreasing and reached $24.66 \%$ in FY2016/17 which was $66.57 \%$ in last FY2015/16.

At last fiscal year 2017/18, the net capital investment has increasing and reached Rs.1064314 million, total operating income also increasing and reached Rs.723640 millions and total operating cost has been decreasing and reached Rs.100929 millions. 
Rishikesh Panthi et al., Saudi J Econ Fin, Feb, 2021; 5(2): 43-50

Similarly, the net capital investment has been increasing and reached Rs.27763 millions, cumulative loss have has been increasing and reached Rs.-115253.27 millions and operating profit to net capital investment percentage has decreasing and reached $21.63 \%$.

In above data analysis shows that net capital investment of government of Nepal in RBBL has been increasing day by day. The operating profit and operating cost also have been increasing. The operating profit has slightly increasing but cumulative loss has been significantly increasing. The percentage ratio of profit was satisfactory compared than other public institutions of Nepal, which was upper than the current interest rate of market price. Hence, the RBBL significantly earning profit but improvement is required to maintain their fiscal discipline for their sustainable growth and development.

\section{Government Share, Loan Investment \& Dividend received from $R B B L$}

The total share and loan investment of Government of Nepal and dividend received from RBBL is very important indicator for measuring performance of public Bank so that in this research also find out the total share and loan investment of Government of Nepal and dividend received from $\mathrm{RBBL}$ in different fiscal year, which is given in table 2 .

Table-2: Government Share investment, Loan\& dividend received from RBBL

\begin{tabular}{|l|c|c|c|c|c|}
\hline S.N. & $\begin{array}{c}\text { Fiscal Year } \\
\text { (FY) }\end{array}$ & $\begin{array}{c}\text { Share Investment (in } \\
\text { millions) }\end{array}$ & $\begin{array}{c}\text { Loan Investment (in } \\
\text { millions) }\end{array}$ & $\begin{array}{c}\text { Total Investment of GONs } \\
\text { (in millions) }\end{array}$ & $\begin{array}{c}\text { Return on } \\
\text { Equity }(\%)\end{array}$ \\
\hline 1. & $2013 / 14$ & 85890 & 3266.32 & 865.70 & 102.96 \\
\hline 2. & $2014 / 15$ & 85890 & 3000 & 8782.04 & NA \\
\hline 3. & $2015 / 16$ & 85890 & 3000 & 352249.61 & 69.56 \\
\hline 4. & $2016 / 17$ & 85890 & NA & NA & 27.37 \\
\hline 5. & $2017 / 18$ & 85890 & 600 & 30727 & 26.34 \\
\hline
\end{tabular}

Source: Original Data from MOF: 2013/14/15/16/17/18

In above table shows that, the share investment of Government of Nepal in RBBL has reached to Rs. 85890 millions constant from FY2013/14 to until FY2017/18 but the loan investment has been slightly decreasing and had reached Rs.600 millions in FY2017/18 which is Rs.3266.32 millions in FY2013/14.

Similarly, government of Nepal had received Rs.30727 millions dividend from RBBL in FY 2017/18 which was only Rs. 865.70 millions in FY2013/14. The return on equity ratio has been highly decreasing and reached $26.34 \%$ in FY 2017/18 which was $102.96 \%$ in FY 2013/14.
The above phenomenon shows that, the rate of government share investment is constant but loan has decreasing tendency. Dividend received ratio has been found in increasing and return on equity percentage was found decreasing trends.

\section{Assets Management of Rastriya Banijya Bank Limited (RBBL)}

Assets Management and shareholder's fund/ Net-worth determine the overall performance of Bank. The role of Shareholder's fund is also very important variable of performance measurement so that the assets performance status of RBBL and shareholder's fund /net-worth are given details in table.-3.

Table-3: Performance Status of PEs contributions on GDP/Revenue \& Shareholder's Fund

\begin{tabular}{|l|c|c|c|c|c|c|}
\hline S.N. & $\begin{array}{c}\text { Fiscal Year } \\
\text { (FY) }\end{array}$ & $\begin{array}{c}\text { Net Fixed } \\
\text { Asset }\end{array}$ & $\begin{array}{c}\text { Current } \\
\text { Asset }\end{array}$ & $\begin{array}{c}\text { Loan } \\
\text { Investment }\end{array}$ & $\begin{array}{c}\text { Cash and Bank } \\
\text { Balance }\end{array}$ & $\begin{array}{c}\text { Shareholder found/Net- } \\
\text { worth (in million) }\end{array}$ \\
\hline 1. & $2013 / 14$ & 4891 & 23200.20 & 490449 & 131381.53 & 12725 \\
\hline 2. & $2014 / 15$ & 4910.65 & 23865.73 & 893827 & NA & 23866 \\
\hline 3. & $2015 / 16$ & 5242.01 & 228946 & 1073896 & 190640.03 & 66758 \\
\hline 4. & $2016 / 17$ & 5121 & 182178 & 1255465 & 44822.12 & 86062 \\
\hline 5. & $2017 / 18$ & 6924 & 15914 & 1021616 & 190052 & 104840 \\
\hline
\end{tabular}

Source: Original Data from MOF: 2013/14/15/16/17/18

In above table shows that RBBL has been capitalized Rs.4910.65 millions net fix asset and Rs.23865.73 millions current asset in FY2014/15 which was respectively Rs.4891 millions and Rs.23200.20 millions in FY2013/14. The loan status has reached Rs.893827 millions and shareholder fund had reached Rs.23866 millions in FY 2014/15 which was subsequently Rs.490449 and Rs.12725 Millions in last FY 2013/14.

Furthermore, net fixed asset has been slightly increasing and reached Rs.5121 millions and current asset has been decreasing and reached Rs.182178 millions in FY2016/17 which was respectively 
Rishikesh Panthi et al., Saudi J Econ Fin, Feb, 2021; 5(2): 43-50

Rs5242.01 millions and Rs. 228946 millions in FY2015/16. Similarly, loan investment and shareholder fund both have been increasing and reached Rs.1255465 millions and Rs. 86062 million respectively Which was subsequently Rs.1073896 million and Rs.66758 million in last FY2015/16.

At last fiscal year 2017/18, net fixed asset has been increasing and reached Rs.6924 million and current asset has been decreasing and reached Rs.15914 million. Again, Loan investment status was found decreasing and reached Rs.1021616 millions but shareholder fund was found increasing than last FY then Reached Rs.104840 million.
In above situation analysis, net fixed asset, bank balance, shareholders fund was increasing trends but current asset, loan investment were decreasing trends. Which was indicates that the rate of investment and business credit supply rate was increasing which is help to determinant the overall performance of RBBL.

\section{Working Capital, Administrative expenditure \& unfunded Liabilities of RBBL}

Employee's generation possibility, administrative expenditure \& unfunded liabilities also impact to determine on RBBL performance so that these all of above variables are given in table -4 .

Table-4: Working Capital, Administrative Expenditure\& Unfunded Liabilities of RBBL

\begin{tabular}{|l|c|c|c|c|c|}
\hline S.N. & $\begin{array}{c}\text { Fiscal } \\
\text { Year (FY) }\end{array}$ & $\begin{array}{c}\text { No. of } \\
\text { Employees }\end{array}$ & $\begin{array}{c}\text { Administrative } \\
\text { expenditure (In } \\
\text { millions) }\end{array}$ & $\begin{array}{c}\text { Ratio of Administrative } \\
\text { expenditure on Operational } \\
\text { Income (\%) }\end{array}$ & $\begin{array}{c}\text { Unfunded Liabilities } \\
\text { of PEs. (In millions) }\end{array}$ \\
\hline 1. & $2013 / 14$ & 2626 & 29797.58 & NA & 2275 \\
\hline 2. & $2014 / 15$ & 2678 & 29132.04 & 48.22 & 12380.05 \\
\hline 3. & $2015 / 16$ & 2672 & 32255 & 29.39 & 8470.34 \\
\hline 4. & $2016 / 17$ & 2467 & 37070 & 55.17 & 0 \\
\hline 5. & $2017 / 18$ & 2248 & 40078 & 39.71 & 0 \\
\hline
\end{tabular}

Source: Original Data from MOF: 2013/14/15/16/17/18

In above table shows that, all together 2678 employees were working in FY 2014/15 which was 2626 in previous FY 2013/14. The Administrative Expenditure has reached Rs 29132.04 million in 2014/15, which was also Rs. 29797.58 millions in last FY 2013/14. The unfunded liabilities of RBBL were found Rs.12380.05 millions in FY 2014/15 which was only Rs. 2275 mission in Previous FY 2013/14.

Furthermore, employees of RBBL have been decreasing and reached 2467 in FY2016/17 which was 2672 in FY2015/16. The administrative expenditure has been significantly increasing and had reached Rs.37070 million in FY2016/17 which was only Rs.32255 million in FY2015/16. The ratio of administrative expenditure on operational income has been increasing and reached $55.17 \%$ which was only $29.39 \%$ in FY $2015 / 16$. The unfounded liabilities had been decreasing and reached Rs.8470.34 million.

Similarly, human working capital of RBBL have been decreasing and reached only 2248 and administrative expenditure has been increasing and reached Rs.40078 millions in last fiscal year 2017/18. The ratio of administrative expenditure on operational income has been decreasing by $39.71 \%$ and unfunded and contingent liabilities have not been founded.

In above trends analysis shows that the performance of RBBL has been going to improvement each and every year and become provide satisfied performance level from last FY B2017/18 to still date.

\section{CONCLUSION}

Rastriya Banijaya Bank Limited was established in Nepal with the main objective of providing institutional business credit for enhancing the production and productivity of the business sector in the country. It is also obvious that, in spite of huge capital investment by government of Nepal in RBBL have been able to provide satisfactory financial credit for business promotion, development, and financial returns on the overall net profit, total operating income operating profit to net capital investment, Government revenue generation and Employees Generation. The rate of Employees generation was found decreasing trends in the research periods. The administrative expenditure was slightly increasing and unfunded liabilities were totally controlled, which indicate that the question about transparency, accountability, productivity and performance of RBBL in Nepal. In additions this, the achievement of RBBL as a public enterprises investment of Government is better than the other sector of public enterprises. The rate of return from RBBL in Nepal is getting better than the current interest rate of market price. The capital output ratio also remained satisfactory the labour productivity also showed littlebit unfavorable trends with a few exceptions. In fact, the all capital output ratio, employee productivity ratio, and value added employee return, share and loan and investment ratio, dividend-received ratio have been up to the mark better than the balance level. RBBL has passed to perform in an efficient manner 
Rishikesh Panthi et al., Saudi J Econ Fin, Feb, 2021; 5(2): 43-50

On the other hand, the role of RBBL has become remaining significant in mobilizing income tax, value added tax and non-taxable tax, public welfare, service delivery, employees generation, Carting, Syndicate controlled, Market controlled, financial crisis management and an emergency situation.

\section{REFERENCES}

1. United Nations. (2005). Public Enterprises: Unresolved Challenged and New opportunities, Department of Economic and Social Affairs. U. N. New York: USA.

2. Lewin, A.Y., \& Minton, J.W. (1986). Determining Organization Effectiveness: another look and an Agenda for Research. Management Science, 32, 514-538.

3. Morin, M.E, \& Audebrand. (1995). Organizational Performance and Meaning of Work: Correcting for Restricted Range enseingnement du management. Catherine Montreal. Quebec.

4. Panthi, R. (2019c). Performance of Agriculture Development Bank Limited in Nepal. SAARJ: Journal of Banking \& Insurance Research (SJBIR), 8(3), 4- 16.

5. Borman, W.C., \& Motowidlo, S.J. (1993). Expanding the criterion doman to include element of contextual performance. In N. Schmitt \& W.C. Borman (eds.). Personnel Selection in organizations, Ssanfrancisco: Jossey- Bass.

6. Shrepherd, W.G. (1965). Economic Performance under public ownership. Yale University Press New Halvon.

7. Pryke, R. (1984). The Nationalized Industries: Policies and Performance since 1968, Martin Robertson Oxford.

8. Millward, R. (1982). The Comparative Performance of public and private ownership. in L.E.Roll (.eds.) The Mixed Economy, Macmillan, London, 59-93

9. Fernandes, P., \& Kreacic, V. (1982). A case book of Public Enterprises Studies. ICPE, Ljubljana.

10. Short, P. (1983). Appraising the role of public enterprises: An International Comparison, IMF Occasional paper, IMF, Washington D.C.

11. Marchand, M, Pestieu, P., \& Tulkens, H. (1984). The Performance of PublicEnterprises concept and Measurement, North Holland, Amsterdam.

12. Kirkpatrick, C., Lee, N., \& Nixon, F.J. (1984). Industrial Structure and policy in less Developing countries. George Allen and Unwin, London.

13. Rees, R. (1984). Public EnterprisesEconomic ( $2^{\text {nd }}$ edition).Widenfeld \& Nicolson, London.

14. Nellis, J. (1986). Public Enterprises in SouthSaharan Africa. World Bank Discussion Paper -1, World Bank, Washington. D.C.

15. Pestieau, P. (1989). Measuring the performance of public enterprises: A most in times of privatization, Annals of public and cooperative Economics, 60(3), 293-305.
16. Anastassiou, Th., \& Doumpos, M. (2000). Multicriteria Evaluation of the performance of public enterprises: The case of Greece, InvestigacionesEuropeas de Direccciony. Economia de la Empresa, 6(3), 11-24.

17. Chen, L.Y., \& Barnes, F.B. (2006). Leadership behaviors and knowledge sharing in professional service firms engaged in strategic alliances. Journal of Applied Management and Entrepreneurship, 11(2), 51-70.

18. Koontz, H., \& Donnell, C. (1993). Introduction to Management. New York McGraw - Hill Inc.

19. Tangen, (2005). Demystifying Productivity and Performance. International Journal of Productivity and Performance Management, 54(1), 34-46.

20. Gresty, D. (2010). Performance Management Assessing the Gap between Theory and Practice in an SME. Master Degree thesis, Department of Business Administration Chester Business School.

21. Panthi, R. (2019a). Performance of Nepal Airlines Corporation and Its Operational Challenges in Nepal. ACADEMICIA: An International Multidisciplinary Research Journal, 9(3), 46-64.

22. Venkatraman, N., \& Rajanujam, V. (1986). Measurement of Business Economic Performance: an examination of method Convergence. Journal of Management Development, 13(1), 109-122.

23. Panthi, R. (2019b). Performance of Public Enterprises and Its Management Challenges in Nepal. South Asian Journal of Marketing \& Management Research (SAJMMR), 9(4), 8-34.

24. Gavrea, C., \& Stegerean, R. (2011). Determinations of Organizational Performance: the cause of Romania. Management and Marketing Challenges for Knowledge Society, 6(2), 285-300.

25. Kehinde, J.S, Jegede, C.A., \& Akinlabi, H.B. (2012). Impact of Leadership Skill and Strategies on Banking Sector Performance: A Survey of Selected Consolidated Banks in Nigeria. The Business \& Management Review, 3(1), 313-319.

26. Banerjee, S., \& Sharma, V. (2017). Performance Analysis Among Private Sector Banks VIA Camels Model. School of Management and Commerce, Sanskriti University, Mathura, Uttar Pradesh: India.

27. Sharma, M. (2014). Performance of Indian Banking Sector-A Comparative Study. EPRA International Journal of Economic \& Business Review, 2(3).

28. Prasad, K.V.N., \& Ravinder, G. (2012). A Camel Model Analysis of Nationalized Banks in India. International Journal for Trade \& Commerce, 1(1), 23-33.

29. Hui, X. (2012). A Comarison of Financial Performance of Commercial Banks: A Case Study of Nepal. African Journal of Business Management, 6(25).

30. Kaur, J., Kaur, M., \& Singh, S. (2015). Financial Performance Analysis of Selected Public Sector Banks: A CAMEL Model Approach. Research Gate, 13(6), 4327-4348. 
Rishikesh Panthi et al., Saudi J Econ Fin, Feb, 2021; 5(2): 43-50

31. Malhotra, P. K. (2013). Performance Appraisal of Indian Public Sector Banks. World Journal of Social Science, 3(3).

32. Chaudhary, G. (2014). Performance Comparison of Private Sector Banks with the Public Sector Banks in India. International Journal of Emerging Research in Management \& Technology, 3(2).

33. Simons, R. (2000). Performance measurement and control systems for implementing Strategy. Text and Cases, Prentice-Hall: New Jersey.

34. Neely, A.D. (1994). Performance Measurement System Design-third phase. Performance Measurement System Design Workbook.

35. Hancott, D.E. (2005). The relationship between transformational leadership and Organizational performance in the largest public companies in Canada. Unpublished Doctoral Dissertation, Capella University, Minneapolis: MN.

36. Schiuma, G., \& Lerro, A. (2008). Intellectual Capital and company's performance improvement. Measuring Business Excellence, 12(2), 3-9.

37. Garnett, J.L., Marlowe, J., \& Pandey, S.K.A (2008). Penetrating the performance predicament: communication as a mediator or moderator of organizational culture's impact on public organizational performance. Public Administration Review, 68(2) 266-281.

38. Green, K.W., \& Inman, R.A. (2007).The impact of JIT-II Selling on Organization Performance.
Industrial Management and Data Systems, 107(7), 1018-1035.

39. Chung R.G., \& Lo, C.L. (2007). The Relationship between Leadership Behaviour and Organizational performance in non-profit organizations, using social welfare charity foundations as an example. Journal of America Academy of Business, 12(1), 83-87.

40. Delaney, J., \& Huselid, M. (1986). The impact of human resource management practices in perceptions of organizational performance. Academy of Management Journal, 39, 349-363.

41. Tippinsand, Michel J., \& Shoi, Ravipreet. S. (2003). It Competency and firm Performance: is Organizational Learning a missing link? Strategic Management Journal, 24, 745-761.

42. Powel, V. (1987). Improving PE Performance: Concepts and Techniques, New Delhi: Oxford and IBM Publishing Co.

43. Fuentes - Fuentes, M. Albacete-Saez, C.A., \& Lloreans-Montes, F.J. (2004). The impact of environmental characteristics on TQM principle and organizational performance. Omega, 32, 425442.

44. Curkovic, S., Vickery, S.K., \& Droge, C. (2000). An empirical analysis of the Competitive dimensions of Quality Performance in the automotive supply industry. International Journal of Operations and Production Management, 20(3), 386-403. 